\title{
Indeks Komposit Pekerjaan Layak di Indonesia Pada Era Pandemi COVID-19
}

(Decent Work Composite Index in Indonesia in the Era of COVID-19 Pandemic)

\author{
Katamso Noto Santoso ${ }^{1 *}$, Suryo Adi Rakhmawan ${ }^{2}$ \\ ${ }^{1,2}$ Badan Pusat Statistik \\ Jl. Dr. Sutomo No 6-8 Jakarta \\ E-mail: katamso.ns@bps.go.id
}

\begin{abstract}
ABSTRAK
Pandemi memberikan dampak pada berbagai lapisan kehidupan sosial ekonomi termasuk ketenagakerjaan. Dampak berupa pengurangan jam kerja, sementara tidak bekerja, pengangguran, atau menjadi bukan angkatan kerja dirasakan baik oleh tenaga kerja formal maupun informal. Terlebih, tenaga kerja informal memang sudah menjadi tenaga kerja yang rentan. Permasalahan tersebut menjadikan perlunya mengetahui bagaimana kondisi kelayakan pekerjaan di Indonesia di masa pandemi. Penelitian ini menghitung Indeks Pekerjaan Layak (IPL) pada masa pandemi di Indonesia bertujuan untuk mengetahui gambaran provinsi di Indonesia agar pihak terkait dalam melakukan perencanaan hingga evaluasi yang matang. Dengan menggunakan analisis faktor, penelitian ini menghasilkan temuan bahwa beberapa daerah ternyata cenderung masih memiliki IPL yang rendah. Artinya pemerintah pusat maupun daerah di wilayah terkait seharusnya semakin bersifat sensitif dan responsif terhadap kelayakan bekerja penduduknya dimulai dari fokus pada variabel-variabel yang berdampak secara signifikan.
\end{abstract}

Kata kunci: COVID-19, Pekerjaan layak, Analisis faktor

\section{ABSTRACT}

The pandemic has an impact on various levels of socio-economic life, including employment. The impact of reducing working hours, temporarily not working, unemployment, or being out of the labour force is felt by formal and informal workers. Moreover, informal workers have become a vulnerable workforce. These problems make it necessary to know how the conditions of employment in Indonesia are during the pandemic. This study calculates the Decent Work Index (DWI) during the pandemic in Indonesia, which aims to find out the description of the provinces in Indonesia so that relevant parties can carry out planning to careful evaluation. This study found that several areas still have low DWI using factor analysis. This means that the central and local governments in the related areas should be more sensitive and responsive to the work worthiness of the population, starting from focusing on variables that have a significant impact.

Keywords: COVID-19, Decent Work, Factor Analysis

\section{PENDAHULUAN}

International Labour Conference (ILO) melalui International Labour Conference pada tahun 1999 memamparkan konsep yang komprehensif tentang pekerjaan layak atau decent work yang merupakan pekerjaan yang menjamin setiap pekerja bekerja secara produktif dan terpenuhinya hak-hak asasi sebagai seorang manusia seperti kebebasan, kesetaraan, keamanan, serta diperlakukan sesuai martabat manusia (Anker et al., 2003). Selain itu, ILO menambahkan bahwa pekerjaan layak harus memberikan fleksibilitas, keamanan, dan dialog. Ketiga dimensi tersebut memungkinkan pencapaian penghasilan yang memadai, kerja yang produktif, waktu kerja yang layak, lingkungan kerja yang aman, stabilitas dan keamanan kerja, jaminan sosial, dialog sosial, serta memungkinkan pekerja untuk menggabungkan pekerjaan, keluarga dan kehidupan pribadi (ILO, 2011).

Dalam Tujuan Pembangunan Berkelanjutan atau Sustainable Development Goals tujuan ke-8 yaitu decent work and economic growth, pekerjaan yang layak untuk semua menjadi salah satu perhatian utama pemerintah dan ILO dalam pertumbuhan ekonomi. Hal tersebut dikarenakan pekerjaan yang layak memiliki kontribusi penting untuk meningkatkan kualitas hidup serta mengurangi kemiskinan sehingga dapat meningkat pertumbuhan ekonomi (Azunu \& Mensah, 2019). Oleh karena itu, pemerintah perlu menyelesaikan berbagai masalah ketenagakerjaan dalam mencapai kondisi pekerjaan yang layak.

Permasalahan ketenagakerjaan pada negara berkembang seperti Indonesia cukup banyak. Hal tersebut dapat dilihat dengan meningkatnya jumlah angkatan kerja di Indonesia pada Agustus 2020 sebanyak 138,22 juta orang, naik 2,36 juta orang dibanding Agustus 2019 (BPS, 2020). Hal tersebut berarti semakin banyak 
penduduk Indonesia yang masuk ke dalam pasar tenaga kerja, meskipun tidak seluruh angkatan kerja beraktivitas bekerja dalam kesehariannya. Meningkatnya tawaran tenaga kerja di pasar tenaga kerja yang tidak sebanding dengan permintaan akan meningkatkan angka pengangguran (Hall, 2003). Meskipun pada kenyataannya, dengan munculnya gig economy pada masa saat ini, akhirnya membuat banyak angkatan kerja yang baru masuk ke pasar tenaga kerja memasuki gig economy atau selanjutnya memilih bekerja pada sektor informal (Abraham et al., 2018). Sektor informal memang mudah untuk dimasuki, hal tersebut diperkuat dengan tingginya persentase pekerja informal yakni sebesar 60.47 persen (BPS, 2020). Akan tetapi, pekerjaan di sektor informal dikategorikan sebagai salah satu pekerjaan kurang layak karena konsekuensi dari sektor informal seperti tidak terdaftar dengan lisensi, belum adanya aturan baku yang mengatur secara detail, serta kurangnya perlindungan yang diberikan kepada para pekerja sektor informal menjadikan para pekerjanya rentan untuk terkena dampak ekonomi maupun sosial (Octavia, 2020).

Di sini lain, wabah pandemi yang berlangsung sejak awal Tahun 2020 di Indonesia dan adanya penerapan pembatasan sosial berskala mikro hingga besar, serta beberapa wilayah dilakukan kebijakan lockdown membuat aktivitas sehari-hari terganggu, terutama para tenaga kerja. Semakin banyak orang yang harus tinggal dan bekerja di rumah, pengurangan mobilitas dan perilaku konsumsi, ujungnya akan berdampak pada sektor yang sebelumnya memang sudah rentan, yaitu para pekerja di sektor informal (Cetrulo et al., 2020). Ketika dilihat lebih mendalam, dampak pandemi ini tidak hanya dirasakan oleh pekerja di sektor informal, namun sektor formal juga terdampak, hingga akhirnya berimbas pada melambatnya perputaran ekonomi makro di Indonesia (Rahman et al., 2020). Dampak yang diberikan atas mewabahnya COVID-19 baik pada pekerja di sektor formal maupun informal dirasakan mulai dari pengurangan jam kerja yang berdampak pada penyusutan output, sementara tidak bekerja, menjadi pengangguran, bahkan menjadi bukan angkatan kerja karena terdampak oleh pandemi (BPS, 2020).

Tenaga kerja yang telah terdampak oleh COVID-19 secara rutin diukur oleh Badan Pusat Statistik (BPS) melalui Survei Angkatan Kerja Nasional yang dilaksanakan setiap semester. Setahun dua kali BPS merilis jumlah penduduk yang terdampak oleh COVID-19 ke dalam empat kelompok. Akan tetapi, penduduk yang tetap bekerja di masa pandemi ini belum tergambarkan kondisinya.

Penelitian ini bertujuan untuk menggali lebih dalam kondisi kelayakan pekerjaan yang dijalani oleh penduduk bekerja. Dengan menggunakan indikator yang mengacu pada kerangka kerja yang digunakan di berbagai negara, penelitian ini mencoba menghitung Indeks Pekerjaan Layak di Indonesia pada masa Pandemi. Sehingga, harapan dari adanya penelitian ini dapat menjadi masukan untuk pemerintah dan pihak terkait dalam pembuatan kebijakan maupun evaluasi pelaksanaannya sehingga Indonesia dapat menjadi negara yang lebih kuat dalam menghadapi dampak Pandemi di bidang sosial ekonomi terutama ketenagakerjaan.

\section{METODE}

Metode analisis yang digunakan dalam penelitian ini adalah analisis faktor. Analisis faktor merupakan analisis multivariat yang digunakan untuk mereduksi atau meringkas variabel yang banyak menjadi variabel baru yang lebih sedikit yang disebut sebagai faktor (Supranto, 2004). Analisis tersebut bertujuan untuk memadatkan informasi yang terkandung pada sejumlah variabel asli ke dalam suatu set variabel (faktor) yang lebih sederhana dengan meminimalisasi hilangnya informasi dari variabel asli (Hair et al., 2010). Analisis faktor merupakan teknik interdependensi yang melibatkan data multivariabel dan digunakan untuk menganalisis variabel-variabel yang diduga memiliki keterkaitan satu sama lain sehingga keterkaitan tersebut dapat dijelaskan dan dikelompokkan pada faktor laten yang tepat (Sharma, 1996).

Dalam analisis faktor, terdapat vektor acak $X$ dengan $\mathrm{p}$ komponen yang memiliki rata-rata $\mu$ dan matriks kovarian $\sum$. Model faktor menyatakan X secara linier dependen dengan beberapa variabel yang tidak terobservasi yang disebut common factor $(\mathrm{F} 1, \mathrm{~F} 2, \ldots, \mathrm{Fm})$, dan sumber variasi lain sejumlah p yaitu $\varepsilon 1, \varepsilon 2$, ..., हp yang disebut error atau specific factor.

\section{Penyusunan Indeks Komposit}

Tahapan penyusunan indeks yang digunakan dalam penelitian ini mengadopsi metode yang digunakan OECD. Berikut tahapan penyusunan indeks komposit dalam penelitian ini:

1. Membangun kerangka kerja teoritis dan pemilihan indikator

Kerangka kerja dalam penelitian ini mengadopsi kerangka kerja International Labor Organization (ILO) yang dipaparkan pada International Conference of Labour Statisticians pada Desember 
2008. Selain itu, pemilihan indikator dalam penelitian ini mengacu pada penelitian Anker et al. (2003) dan ILO (2011).

2. Melakukan standarisasi data

Metode standarisasi yang digunakan dalam penelitian ini adalah z-standardized.

3. Melakukan analisis faktor

Tahapan analisis faktor meliputi uji kelayakan data, reduksi indikator, pembentukan faktor, rotasi faktor hingga menghasilkan nilai skor faktor.

4. Menentukan penimbang

Pada penelitian ini penimbang yang digunakan adalah unequal weighting, dimana penimbang didapatkan dari proporsi explained varians oleh setiap faktor dengan total explained varians (OECD, 2008).

5. Melakukan agregasi

Pada penelitian ini, metode agregasi yang digunakan adalah agregasi linear (linear aggregation).

$$
I P L_{j}=\sum_{j=1}^{j} \sum_{i=1}^{k} W_{i} f_{i j}^{\prime}
$$

Keterangan:

$I P L_{j}:$ Indeks Pekerjaan Layak provinsi ke-j

$W_{i}$ : penimbang faktor ke-i

$f_{i j}^{\prime}$ : skor faktor ke-i provinsi ke-j setelah normalisasi

6. Melakukan visualisasi data

Indeks komposit yang terbentuk ditampilkan dalam bentuk peta. Visualisasi dalam bentuk choropleth memudahkan dalam membaca hasil indeks komposit yang terbentuk.

\section{Data dan Sumber Data}

Data yang digunakan pada penelitian ini merupakan indikator-indikator yang dapat menggambarkan pekerjaan layak di Indonesia tahun 2020. Pemilihan indikator mengacu pada kerangka kerja yang dipresentasikan pada 18th International Conference Labour Statisticians pada bulan Desember 2008. Kerangka kerja tersebut mencakup sepuluh elemen substantif yang sesuai dengan empat pilar strategis dari agenda pekerjaan layak, yaitu hak ditempat kerja, pekerjaan yang penuh dan produktif, perlindungan sosial, dan dialog sosial (Anker et al., 2003; ILO, 2011). Apabila indikator yang disarankan ILO tidak tersedia maka pada penelitian ini menggunakan proxy variabel. Berdasarkan ketersediaan data, diperoleh indikatorindikator yang dapat menggambarkan pekerjaan layak di Indonesia tahun 2020 (Tabel 1).

Sumber data yang digunakan merupakan data sekunder dari Survei Angkatan Kerja Nasional (SAKERNAS) Agustus Tahun 2020 serta Survei Sosial Ekonomi Nasional (SUSENAS) KOR Tahun 2020 yang dikumpulkan oleh Badan Pusat Statistik (BPS).

Tabel 1. Indikator yang menggambarkan pekerjaan layak tahun 2020

\begin{tabular}{cccc}
\hline No & Indikator & Simbol & Sumber Data \\
\hline 1 & Employment to Population Rate (EPR) & X1 & Sakernas \\
2 & Tingkat Pengangguran Terbuka & X2 & Sakernas \\
3 & Tingkat Pengangguran Terbuka Usia Muda & X3 & Sakernas \\
4 & NEET & X4 & Sakernas \\
5 & Tingkat Pekerja Informal & X5 & Sakernas \\
6 & Tingkat Setengah Pengangguran & X6 & Sakernas \\
7 & Low Pay Rate & X7 & Sakernas \\
8 & Angka Pekerja Anak & X8 & Sakernas \\
9 & Gender Wage Gap & X9 & Sakernas \\
10 & Persentase Perempuan yang bekerja sebagai manajer & X10 & Sakernas \\
11 & Proporsi pekerja disabilitas & X11 & Sakernas \\
12 & Persentase pekerja yang mempunyai jaminan sosial & X12 & Sakernas \\
13 & Persentase pekerja yang terganggu pekerjaannya akibat & X13 & Susenas \\
14 & keluhan kesehatan & & X14 \\
\hline
\end{tabular}




\section{HASIL DAN PEMBAHASAN}

Pembentukan indeks pekerjaan layak dimulai dengan melakukan standarisasi serta menyeragamkan arah dari masing-masing indikator. Pada penelitian ini, arah dari tiap indikator dibuat positif. Semakin tinggi nilai indikator maka wilayah tersebut memiliki indeks pekerjaan layak yang tinggi. Apabila suatu indikator memiliki arah yang negatif maka indikator tersebut perlu diubah arahnya. Hal tersebut bertujuan agar dalam tahap selanjutnya tidak terjadi kesalahan interpretasi. Setelah tahap standardisasi serta penyeragaman arah indikator, dilakukan proses selanjutnya adalah reduksi indikator. Dalam melakukan reduksi indikator perlu mempertimbangkan nilai Measure of Sampling Adequacy (MSA) dan nilai communalities. Variabel atau indikator yang memiliki nilai MSA kurang dari 0,5 harus direduksi secara bertahap dan variabel/indikator yang memiliki nilai komunalitas kurang dari 0,5 juga harus direduksi (Hair et al., 2010). Berdasarkan proses reduksi indikator, diperoleh enam indikator terpilih untuk membentuk indeks pekerjaan layak tahun 2020 (Tabel.2).

Tabel 2 menampilkan statistik deskriptif dari indikator yang terpilih. Standar deviasi yang relatif besar ditunjukkan pada variabel Persentase Pekerja yang mempunyai jaminan sosial, yaitu senilai 10,18. Hal ini berarti bahwa variabel tersebut memiliki variasi nilai yang cukup beragam pada seluruh provinsi di Indonesia. Indikasi dari adanya hal ini adalah bahwa masih terdapat kesenjangan jaminan sosial yang dimiliki oleh pekerja dikarenakan masih rencahnya pendapatan yang dimiliki oleh mayoritas pekerja di Indonesia, terutama para pekerja informal (Purba et al., 2021). Hal ini selaras dengan deskripsi dari variabel tingkat pekerja informal, yang menunjukkan bahwa sebagian besar penduduk bekerja merupakan pekerja informal yang berada di angka 60,67 persen. Selain itu, tingkat pengangguran terbuka di usia muda lebih besar dibandingkan tingkat pengangguran terbuka secara keseluruhan. Selanjutnya, standar deviasi terendah adalah pada variabel Angka pekerja Anak. Hal ini menunjukkan bahwa provinsi di Indonesia masih secara menyeluruh memiliki kantung pekerja anak dengan persentase yang relatif homogen. Keberadaan pekerja anak yang belum sesuai dengan komitmen pemerintah dalam rangka menghapus pekerja anak karena pekerja anak berhubungan dengan eksploitasi pekerjaan yang berbahaya, akses terhambat pembangunan fisik, psikologis dan sosial pendidikan (Sulistiyono et al., 2019).

Tabel 2. Statistik deskriptif dari indikator yang terpilih

\begin{tabular}{ccccccc}
\hline No & Indikator & Simbol & Mean & St.Dev & Min & Max \\
\hline 1 & Employment to Population Rate & $\mathrm{X} 1$ & 63,97 & 3,71 & 56,82 & 70,14 \\
2 & Tingkat Pengangguran Terbuka & $\mathrm{X} 2$ & 6,03 & 2,01 & 3,32 & 10,95 \\
3 & Tingkat Pengangguran Terbuka Usia Muda & $\mathrm{X} 3$ & 17,03 & 5,32 & 8,72 & 31,18 \\
4 & Tingkat Pekerja Informal & $\mathrm{X} 5$ & 60,67 & 9,76 & 35,41 & 79,92 \\
5 & Tingkat Setengah Pengangguran & $\mathrm{X} 6$ & 10,69 & 2,66 & 5,75 & 16,83 \\
6 & Low Pay Rate & $\mathrm{X} 7$ & 30,13 & 4,26 & 22,35 & 37,58 \\
7 & Angka Pekerja Anak & $\mathrm{X} 8$ & 3,85 & 1,62 & 1,19 & 7,89 \\
8 & Gender Wage Gap & $\mathrm{X} 9$ & 17,74 & 7,01 & $-6,02$ & 30,25 \\
9 & Persentase pekerja yang mempunyai jaminan & $\mathrm{X} 12$ & 29,49 & 10,18 & 14,05 & 58,32 \\
& sosial & $\mathrm{X} 14$ & 10,14 & 1,27 & 7,10 & 12,73 \\
\hline & Job Tenure & & & & &
\end{tabular}

Sumber: Data diolah

Setelah indikator sesuai dengan literatur yang digunakan, maka perlu dilakukan uji kelayakan data. Dalam menguji kelayakan suatu kumpulan data, dilakukan uji Kaiser-Meyer-Olkin (KMO) dan Uji Statistik Bartlett. Uji Kaiser-Meyer-Olkin (KMO) mengindikasikan ukuran kecukupan pengambilan sampel. Nilai KMO yang lebih besar dari 0,7 dikategorikan cukup untuk dilakukan analisis faktor (Sharma, 1996). Berdasarkan Tabel 3, nilai KMO pada indeks yang akan dibentuk adalah sebesar 0,763 yang artinya bahwa data dikategorikan cukup untuk dilakukan analisis faktor. Kemudian dilakukan Uji Statistik Bartlett yang bertujuan untuk menguji hipotesis bahwa matriks korelasi merupakan matriks identitas, yang artinya antar indikator tidak ada hubungan sehingga tidak bisa dilakukan analisis faktor. Berdasarkan Tabel 3, hasil uji statistik Bartlett menunjukkan hasil yang signifikan ( $p$-value<0,000), sehingga matriks korelasi bukan matriks identitas yang artinya bahwa antar indikator memiliki hubungan sehingga dapat dilakukan analisis faktor.

Dalam penelitian ini, jumlah faktor ditentukan menggunakan scree plot dan kaidah kriteria Kaiser. Kaidah kriteria Kaiser merupakan kaidah penentuan faktor dominan dengan melihat faktor-faktor yang 
memiliki eigenvalue bernilai lebih dari satu (OECD, 2008). Berdasarkan aturan tersebut maka dari sepuluh indikator yang terpilih dapat ditentukan tiga faktor dominan (Gambar 1). Tiga faktor dominan yang terbentuk tersebut dapat menjelaskan 77,70 persen varians pekerjaan layak di tingkat provinsi.

Tabel 3. KMO dan Uji Bartlett

\begin{tabular}{lll}
\hline Kaiser Meyer Olkin Measure of Sampling Adequacy & & 0,763 \\
\hline Bartlett's Test of Sphericity & Approx. Chi Square & 239,505 \\
& Df & 45 \\
& Sig. & 0,000 \\
\hline
\end{tabular}

Setelah terbentuk tiga faktor, maka perlu menentukan indikator dominan dalam suatu faktor yang dilihat berdasarkan loading factor terbesar dari suatu indikator. Setelah itu, diberikan penamaan untuk tiap faktor berdasarkan indikator dominan penyusun faktor (Hair et al., 2010). Pada Tabel 4, indikator dominan yang menyusun faktor pertama adalah rasio orang yang bekerja, tingkat pengangguran terbuka, tingkat pengangguran terbuka usia muda, dan angka pekerja anak. Oleh karena itu, faktor satu dinamakan sebagai hak dan kesempatan kerja karena indikator penyusun faktor pertama merupakan indikator variabel yang menggambarkan kesempatan kerja dan hak di tempat kerja salah satunya ialah penghapusan pekerja anak (Jayasooria, 2016).

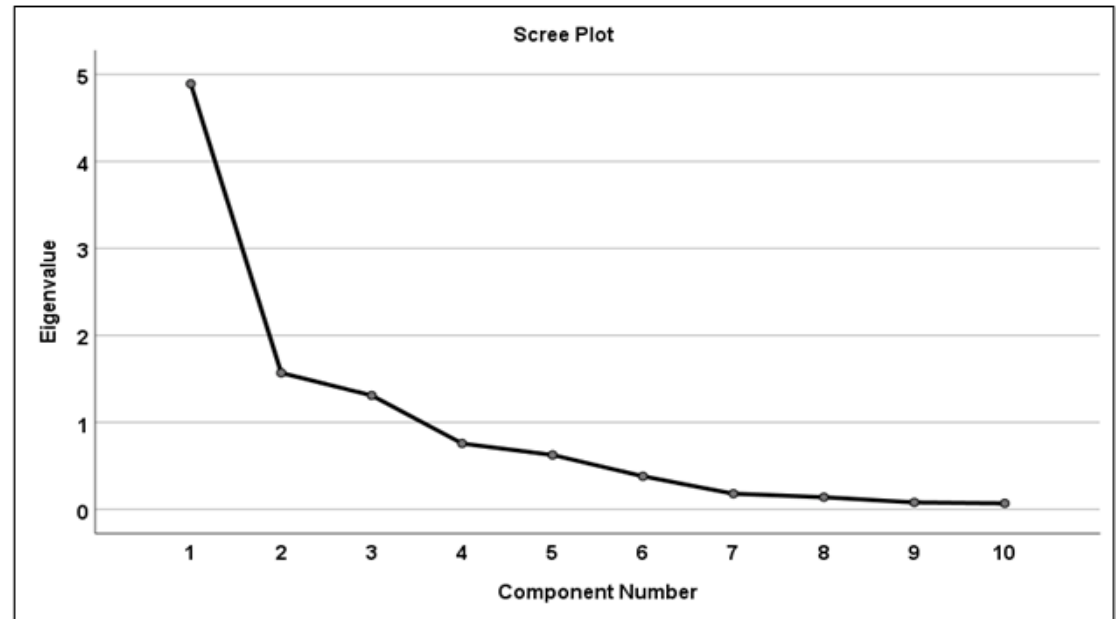

Gambar 1. Scree plot Analisis Faktor Pembentukan Indeks

Tabel 4. Faktor Indeks Pekerjaan Layak (IPL) di Indonesia Tahun 2020

\begin{tabular}{|c|c|c|c|c|c|}
\hline & Faktor & Indikator & Eigenvalue & $\begin{array}{c}\text { Percentage Variance } \\
\text { Explained }\end{array}$ & Penimbang \\
\hline 1 & $\begin{array}{l}\text { Hak dan Kesempatan } \\
\text { kerja }\end{array}$ & $\begin{array}{l}\text { Employment to Population Rate } \\
\text { Tingkat Pengangguran Terbuka } \\
\text { Tingkat Pengangguran Terbuka } \\
\text { Usia Muda } \\
\text { Angka Pekerja Anak }\end{array}$ & 4,89 & 32,77 & 0,42 \\
\hline 2 & $\begin{array}{l}\text { Stabilitas dan jaminan } \\
\text { pekerjaan }\end{array}$ & $\begin{array}{l}\text { Tingkat Pekerja Informal } \\
\text { Tingkat Setengah Pengangguran } \\
\text { Persentase pekerja yang } \\
\text { mempunyai jaminan sosial } \\
\text { Job Tenure }\end{array}$ & 1,57 & 29,60 & 0,38 \\
\hline 3 & $\begin{array}{l}\text { Pendapatan dan } \\
\text { kesetaraan pekerjaan }\end{array}$ & $\begin{array}{l}\text { Low Pay Rate } \\
\text { Gender Wage Gap }\end{array}$ & 1,31 & 15,33 & 0,20 \\
\hline
\end{tabular}

Faktor kedua selanjutnya disebut sebagai stabilitas dan jaminan kerja yakni terdiri atas tingkat pekerja informal, tingkat setengah pengangguran, dan persentase pekerja yang mempunyai jaminan sosial, dan job tenure. Variabel tersebut cukup menggambarkan stabilitas dan jaminan seseorang yang bekerja (Bramas, 2018). Selanjutnya, faktor ketiga disebut sebagai pendapatan dan kesetaraan di pekerjaan yang terdiri atas Low Pay Rate dan Gender Wage Gap. Kedua variabel ini menjadi indikator yang seringkali menggambarkan 
bagaimana kesenjangan dan diskriminasi terjadi antar kelompok penduduk (Kunze, 2018). Persentase varians yang terjelaskan pada faktor pertama sebesar 32,77 persen, faktor kedua sebesar 29,60 persen, sedangkan pada faktor ketiga sebesar 15,33 persen.

Arah dari tiap faktor terhadap indeks pekerjaan layak telah ditentukan pada awal penelitian yaitu arah positif, yang artinya semakin tinggi kesempatan dan hak di tempat kerja maka semakin tinggi pula indeks pekerjaan layak. Selain itu semakin tinggi stabilitas dan jaminan pekerjaan maka semakin tinggi pula indeks pekerjaan layak serta semakin tinggi pendapatan dan kesetaraan pekerjaan maka semakin tinggi pula indeks pekerjaan layak. Selanjutnya, dalam proses penghitungan faktor, setiap variabel pada masing-masing faktor dihitung menggunakan unequal weighting. Skema unequal weighting artinya bahwa tiap variabel memiliki peran yang berbeda dalam membentuk indeks komposit, peran tersebut tergambarkan dari bagaimana faktor memberikan kontribusi terhadap nilai indeksnya (Cutter et al., 2003; Smith, 1974).

Setelah ditentukan jumlah faktor dominan, arah faktor, dan penimbang faktor maka akan didapatkan nilai skor faktor untuk setiap faktor. Nilai skor faktor yang terbentuk masih berupa $z$-score. Hal tersebut akan menyulitkan dalam analisis karena tidak dapat mengetahui nilai maksimum dan minimum yang dapat dicapai (The Economist Group, 2019). Oleh karena itu, untuk memudahkan dalam melakukan interpretasi, nilai skor faktor ditransformasi menjadi suatu skor yang memiliki nilai minimum 0 dan nilai maksimum 100, yaitu dengan melakukan normalisasi min-max dikali 100. Langkah tersebut telah dilakukan di penelitian-penelitian lain dalam proses penyusunan indeks, salah satunya adalah active ageing index (European Commission \& UNECE, 2019).

Selanjutnya untuk memperoleh Indeks Pekerjaan Layak (IPL) dilakukan penjumlahan hasil perkalian antara penimbang dengan skor faktor yang sudah dinormalisasi sesuai dengan formula sebagai berikut:

$$
\text { IPL }=(0,42 \times \text { Faktor } 1)+(0,38 \times \text { Faktor } 2)+(0,20 \times \text { Faktor } 3)
$$

IPL disajikan tiap provinsi melalui Gambar 2. Ukuran indeks dalam rentang antara 0 dan 100. Nilai indeks yang lebih tinggi di suatu wilayah menggambarkan bahwa kondisi pekerjaan layak di wilayah tersebut lebih layak dibandingkan dengan wilayah lain. Pada Gambar 2, wilayah yang memiliki nilai IPL yang tinggi maka warnanya semakin terang sedangkan wilayah yang memiliki IPL rendah maka warnanya akan semakin gelap. Berdasarkan peta tersebut, sebagian besar wilayah di pulau jawa memiliki warna yang relatif terang yang artinya pada masa pandemi tahun 2020, kondisi pekerjaan layak di pulau jawa sebagian besar relatif lebih baik dibandingkan dengan provinsi di pulau lain terutama di Nusa Tenggara dan Sulawesi.

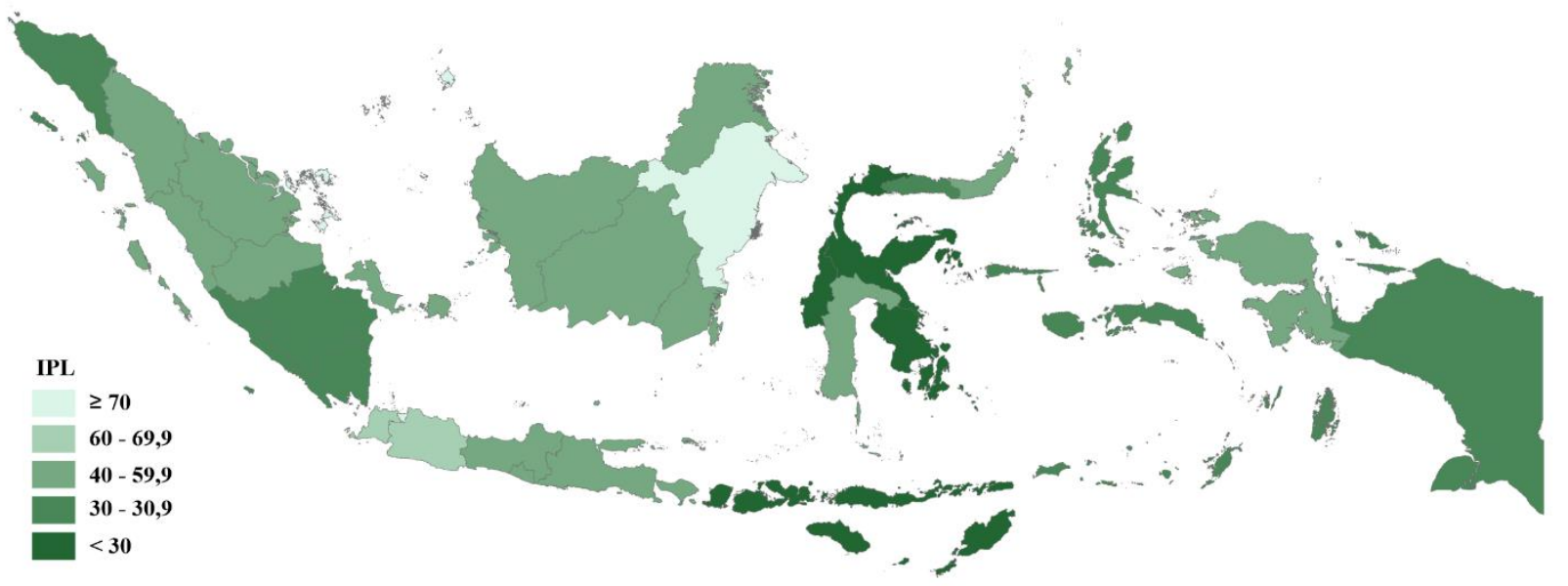

Sumber: Data Diolah

Gambar 2. Sebaran nilai Indeks Pekerjaan Layak

Provinsi yang dengan IPL tertinggi ialah provinsi Kepulauan Riau, DKI Jakarta, dan Kalimantan Timur dengan nilai IPL sebesar 74.42, 72.23, dan 71.14. Berdasarkan nilai Indeks Pekerjaan Layak tersebut, dapat digambarkan bahwa pada ketiga wilayah tersebut kondisi pekerjaannya lebih layak dibandingkan dengan provinsi lain. Sedangkan, provinsi dengan Indeks Pekerjaan Layak terendah ialah provinsi Nusa Tenggara Barat, Sulawesi Barat, dan Nusa Tenggara Timur dengan nilai IPL sebesar 25.57, 23.92, dan 20.56. Kondisi tersebut terlihat dari Gambar 2 yang menggambarkan bahwa wilayah tersebut berwarna gelap.

Untuk mengetahui validitasnya, indeks yang dibentuk dapat dikorelasikan dengan indeks lain yang telah terjamin validitasnya (OECD, 2008). IPL berkaitan dengan bagaimana seseorang dapat bekerja dengan pekerjaan yang layak sehingga dapat menunjang kesejahteraannya baik secara sosial, ekonomi, maupun kesehatan. Indeks valid yang mengukur kesejahteraan di Indonesia dengan dimensi yang luas adalah Indeks 
Pembangunan Manusia (Hopkins, 1991). Selain itu, pekerjaan yang layak akan menunjang seseorang untuk secara produktif bekerja (Anker et al., 2003). Sehingga, selain IPL dikorelasikan dengan IPM, juga akan dikorelasikan dengan Produktivitas Tenaga Kerja. Produktivitas tenaga dalam penelitian ini didapatkan dari output per tenaga kerja, yaitu PDRB riil per jumlah penduduk bekerja. Hasil pengujian korelasi yang dilakukan dapat dilihat pada Tabel 5 menunjukkan bahwa terdapat korelasi yang signifikan, positif, dan relatif cukup kuat antara IPL dengan kedua ukuran lain, yaitu IPM dan Produktivitas. Dengan demikian, indeks yang terbentuk dapat dikatakan valid.

Tabel 5. $\quad$ Uji Korelasi Indeks Pekerjaan Layak dengan Indeks lain

\begin{tabular}{ccc}
\hline Statistics & IPM & Produktivitas Tenaga Kerja \\
\hline Pearson Correlation & $0,685^{* *}$ & $0,642^{* *}$ \\
Sig. (2-tailed) & 0,000 & 0,000 \\
$\mathrm{~N}$ & 34 & 34 \\
\hline
\end{tabular}

** Correlation is significant at the 0,00 level

Korelasi antara IPL dengan IPM juga dapat digunakan sebagai analisis dekomposisi indeks. Dekomposisi indeks adalah salah satu cara untuk mengetahui lebih dalam mengenai indeks yang terbentuk (OECD, 2008). Dekomposisi indeks berguna untuk menjelaskan kondisi yang melatarbelakangi terbentuknya nilai indeks komposit pada suatu wilayah berdasarkan penyusunnya. Dekomposisi indeks juga dapat menjelaskan pencapaian tiap provinsi berdasarkan faktor-faktor yang terbentuk sehingga analisis yang dilakukan lebih komprehensif. Dekomposisi pertama adalah faktor yang memiliki kontribusi terbesar dalam pembentukan IPL, yaitu faktor kesempatan dan hak dalam bekerja. Jika korelasi antara IPL dengan IPM cukup signifikan, maka faktor kesempatan dan hak dalam bekerja memegang peranan penting karena nilai percentage variance explained yang tinggi, yaitu hampir mencapai 32,77 persen.

IPM adalah indeks yang mengukur secara sosial, ekonomi, dan kesehatan pada populasi di suatu wilayah dalam mencapai kesejahteraan mereka. IPM memiliki dua konstruksi dasar, yaitu bagaimana gambaran dari kemampuan seseorang, seperti kesehatan dan pengetahuan yang lebih baik, serta kemampuan yang lebih memadai; dan bagaimana seseorang dapat mengoptimalisasi kemampuan yang dimiliki, untuk aktivitas yang produktif, partisipasi di bidang sosial, kultural, dan politis (OECD, 2017). Mengikuti konsep tersebut, dengan demikian ada korelasi antara faktor kesempatan dan hak dalam bekerja yang baik, dengan angka IPM yang baik pula. Hal tersebut karena dalam faktor kesempatan dan hak kerja, tergambar variabel mengenai bagaimana pengambil kebijakan dapat mengatur pasar tenaga kerja untuk menjaga neraca supply and demand tenaga kerja. Ketika suatu wilayah dapat menjaga kompetisi pasar tenaga kerja hingga menekan angka pengangguran, maka hal tersebut berkaitan dengan kesejahteraan penduduknya (Yusuf \& Dai, 2020).

Dekomposisi yang selanjutnya dilakukan untuk melihat faktor yang diindikasikan berkaitan dengan masa pandemi, yaitu faktor stabilitas dan jaminan di pekerjaan. Faktor yang terdiri atas variabel pekerja informal, setengah pengangguran, job tenure, dan persentase pekerja yang memiliki jaminan sosial tersebut berkorelasi karena pada masa pandemi, tenaga kerja yang sangat rentan terdampak adalah tenaga kerja informal, terutama bagi negara Indonesia yang termasuk dalam negara berkembang dan banyak sektor ekonomi informal yang masih berada pada posisi informal tradisional (Perry et al., 2007).

Kesehatan merupakan modal dasar dan utama dalam proses pembangunan sosial dan ekonomi baik secara mikro maupun makro (Todaro \& Smith, 2012). Rendahnya IPL di Provinsi wilayah Jawa diindikasikan karena dalam masa pandemi, kesehatan yang menjadi faktor utama penggerak roda sosial dan ekonomi masyarakat, telah mengalami pengurangan kualitas. Hasil penghitungan indeks ini juga sejalan dengan studi di beberapa negara lain yang membuktikan bahwa wilayah dengan pembangunan fasilitas yang lebih baik dan terdigitalisasi, akan linear dengan kerentanan pekerjanya, terutama jika di negara berkembang yang masih memiliki pekerja informal (ILO, 2021). Pekerja informal adalah pekerja dengan perlindungan atau jaminan sosial yang minim, hal ini berkaitan erat dengan bagaimana pekerja informal akan rentan untuk masuk ke dalam jurang pekerjaan tidak layak (Abraham et al., 2018). Ditambah lagi dengan adanya pandemi COVID-19, posisi mereka semakin terpojok dan hanya memiliki dua pilihan dalam bekerja yaitu harus siap dengan risiko terpapar oleh virus atau mereka harus siap kehilangan aktivitas utama mereka (Cetrulo et al., 2020).

\section{KESIMPULAN DAN SARAN}

Indeks Pekerjaan Layak cukup dapat menggambarkan bagaimana kesejahteraan pekerja di Indonesia, terutama di masa pandemi yang banyak memberikan dampak kepada pekerja informal. Faktor yang memiliki kontribusi terbesar dalam penyusunan IPL adalah hak dan kesempatan kerja karena dengan semakin 
terbukanya kesempatan pekerja untuk dapat produktif di pasar tenaga kerja, akan semakin memperbesar peluang bagi para pekerja untuk dapat meningkatkan kualitas hidupnya.

Di sisi lain, masih tingginya pekerja informal di Indonesia menjadikan perlunya perhatian pemerintah kepada pekerja informal dan juga pelaku usaha sektor informal. Tingkat pekerja informal yang menjadi salah satu variabel yang berkontribusi pada faktor kedua IPL, dalam masa pandemi dapat menjadi gerbang bagi para pekerja untuk menjadi pengangguran (Purba et al., 2021). Ditambah lagi, di Indonesia sekarang sudah mulai jamak para pekerja independent contractor, para pekerja gig economy yang kebanyakan berada menjadi tenaga kerja informal. Hal tersebut terbukti dengan rendahnya angka Logistic Performance Index (LPI) Indonesia yang berada di bawah India, Thailand, dan jauh di bawah Jerman atau Jepang (Wong \& Tang, 2018).

Peran pemerintah dalam menjaga dan meningkatkan kelayakan pekerjaan di Indonesia yang dapat diukur melalui IPL terutama di masa pendemi mutlak diperlukan. Faktor yang paling berkontribusi, hak dan kesempatan kerja menjadi faktor utama yang harus dijaga, langkah yang dapat dilakuan adalah melalui aspek legal. Membuka kesempatan kerja meski banyak melalui digital atau gig worker memang dapat mengurangi angka pengangguran, namun tetap harus dijaga kelayakan pekerjanya seperti menjaga upah minimum di setiap wilayah sehingga dapat menjaga produktivitas pekerja serta memberikan jaminan sosial kepada pekerja informal modern yang mulai ramah terhadap aspek legalitas. Sehingga, melalui dua langkah tersebut, hak dan kesempatan kerja pekerja dapat dijaga baik oleh pemerintah.

\section{DAFTAR PUSTAKA}

Abraham, K. G., Haltiwanger, J. C., Sandusky, K., \& Spletzer, J. R. (2018). Measuring the Gig Economy: Current Knowledge and Open Issues. In National Bureau of Economic Research.

Anker, R., Chernyshev, I., Egger, P., Mehran, F., \& Ritter, J. A. (2003). Measuring decent work with statistical indicators. International Labour Review, 142(2), 147-178. https://doi.org/10.1111/j.1564913x.2003.tb00257.x

Azunu, R., \& Mensah, J. K. (2019). Local economic development and poverty reduction in developing societies: The experience of the ILO decent work project in Ghana. Local Economy, 34(5), 405-420. https://doi.org/10.1177/0269094219859234

BPS. (2020). Keadaan Ketenagakerjaan Indonesia Agustus 2020. Badan Pusat Statistik, XXiI, 05 N(91), 120.

Bramas, Q. (2018). The Stability and the Security of the Tangle. HAL, 2.

Cetrulo, A., Guarascio, D., \& Virgilito, M. E. (2020). Working from Home and the Explosion of Enduring Divides: Income, Employment, and Safety Risk (Vol. 38).

Cutter, S. L., Boruff, B. J., \& Shirley, W. L. (2003). Social vulnerability to environmental hazards. Social Science Quarterly, 84(2), 242-261. https://doi.org/10.1111/1540-6237.8402002

European Commission, \& UNECE. (2019). 2018 Active Ageing Index: Analytical Report. October.

Hair, J. F., Black, W. C., Babin, B. J., \& Anderson, R. E. (2010). Multivariate Data Analysis.pdf (p. 758). Prentice Hall International. https://doi.org/978-0138132637

Hall, R. E. (2003). Modern Theory of Unemployment Fluctuations: Empirics and Policy Applications. The American Economic Review, 93(2), 145-150.

Hopkins, M. (1991). Human development revisited: A new UNDP report. World Development, 19(10), 1469-1473. https://doi.org/10.1016/0305-750X(91)90089-Z

ILO. (2011). Decent work for domestic workers. In International Labour Conference.

ILO. (2021). Working from home From invisibility to decent work.

Jayasooria, D. (2016). Sustainable Development Goals and Social Work: Opportunities and Challenges for Social Work Practice in Malaysia. Journal of Human Rights and Social Work, 1(1), 19-29. https://doi.org/10.1007/s41134-016-0007-y

Kunze, A. (2018). The Gender Wage Gap in Developing Countries. In The Oxford Handbook of Women and the Economy (pp. 269-294). Oxford University Press.

Octavia, J. (2020). Towards a national database of workers in the informal sector: COVID-19 pandemic response and future recommendations. CSIS Comentaries, August, 1-8.

OECD. (2008). Handbook for Constructing Composite Indicators : Methodology and User Guide (Vol. 63, Issue 5). https://doi.org/10.1111/jgs.13392

OECD. (2017). Multi-dimensional Review of Paraguay. Volume 1. Initial Assessment. Overview (Vol. 1).

Perry, G. E., Maloney, W. . F., Arias, O. S., Fajnzylber, P., Mason, A. D., \& Saavedra-Chanduvi, J. (2007). Informality: Exit and Exclusion. In The World Bank (Vol. 57, Issue c). The world Bank. 
Purba, Y. A., Aini, Y. N., Asiati, D., \& Ngadi, N. (2021). Kesenjangan Kepesertaan Jaminan Sosial Tenaga Kerja Di Indonesia: Analisis Data Sakernas 2018. Jurnal Ketenagakerjaan, 15(2). https://doi.org/10.47198/naker.v15i2.72

Rahman, A., Jasmin, A., \& Schmillen, A. (2020). The Vulnerability of Jobs to COVID-19: The Case of Malaysia The Vulnerability of Jobs to COVID-19: The Case of Malaysia 1.

Sharma, S. (1996). Applied Multivariate Techniques. John Wiley and Sons.

Smith, K. W. (1974). On Estimating the Reliability of Composite Indexes Through Factor Analysis. Sociological Methods and Research, 2(4), 485-510.

Sulistiyono, T., Arifin, R., Sumardiana, B., \& Ramada, D. P. (2019). Legal Protection to Child Labour: The Effectiveness of National Criminal Law and International Law Instrument (A Case Study of Indonesia and China). International Journal of Business, Economics and Law, 18(4), 45-52.

Supranto, J. (2004). Analisis Multivariat: Arti dan Interpretasi. PT. Rineka Cipta.

The Economist Group. (2019). Annual Report 2018. In AIMS Mathematics (Vol. 4, Issue 1). https://doi.org/10.3934/Math.2019.1.166

Todaro, M. P., \& Smith, S. C. (2012). Economic Developement.

Wong, W. P., \& Tang, C. F. (2018). The major determinants of logistic performance in a global perspective: evidence from panel data analysis. International Journal of Logistics Research and Applications, 21(4), 431-443. https://doi.org/10.1080/13675567.2018.1438377

Yusuf, L. A., \& Dai, S. I. (2020). The Impact of Unemployment and Human Development Index on Poverty in Gorontalo Province 2008-2017. Jambura Equilibrium Journal, 2(1), 7-16.

https://doi.org/10.37479/jej.v2i1.4495 